\title{
THE CUSTOMERS' PERCEPTION OF THE SELLERS IN THE CONTEXT OF GENDER DIFFERENCES
}

\author{
Jana Koval'ová ${ }^{1}$ \\ Ivana Ondrijová ${ }^{2}$ \\ Dagmara Ratnayake Kaščáková ${ }^{3}$
}

Received: October 16, 2018 / Revised: January 10, 2019/ Accepted: March 12, 2019

(C) Association of Economists and Managers of the Balkans, 2019

\begin{abstract}
Personal selling has its own specifics and allows sellers to interact directly with the customer. The aim of the proposed paper is to find out statistically significant differences in the perception factor affecting personal selling from the customer's perspective in the context of gender differences. A differential analysis was conducted on the sample of 243 respondents (112 male customers and 131 female customers); on the basis of the data obtained by means of an original methodology for detecting the factors influencing the customers' perception of the sellers in personal selling. Gender differences in customer perceptions were confirmed in six items of observed factors: seller's image, seller's willingness and empathy, and his or her communication skills. The results of the analysis confirmed the existence of statistically significant differences between the male and the female in their perception of the sellers. Based on these results it may be concluded that, male and female differently view the seller's image, his or her willingness and empathy towards customers, as well as its communication skills.
\end{abstract}

Keywords: Gender differences, personal selling, buying behavior, seller

\section{JEL Classification M31}

This paper was presented at the Second International Scientific Conference on IT, Tourism, Economics, Management and Agriculture - ITEMA 2018 - November 8, 2018, Graz, Austria, www.itema-conference.com

Dagmara Ratnayake Kaščáková

dagmara.ratnayake-kascakova@unipo.sk

Prešovská univerzita v Prešove, Fakulta manažmentu, Konštantínova 16, 08001 Prešov, Slovakia Prešovská univerzita v Prešove, Fakulta manažmentu, Konštantínova 16, 08001 Prešov, Slovakia Prešovská univerzita v Prešove, Fakulta manažmentu, Konštantínova 16, 08001 Prešov, Slovakia 


\section{CHARACTERISTICS OF PERSONAL SELLING}

Personal selling is a part of the communication mix and is a tool for personal communication with customers. The seller, individually and without time, perceives the customer's response, allowing him or her to interact and formulate a sales conversation. Personal selling is based on offer and the subsequent sales to the customers. Personal selling is described as a face-to-face communication that aims to provide information, presentations, convince a specific public, or build long-term relationships with customers (Pelsmacker et al. 2003). According to Kotler and Keller (2013), personal selling is a process of support and oral presentation of products to sell and convince potential customers. It is an effective tool of marketing communication, but also the most costly way of advertising. Personal selling is defined according to Kita et al. (2005) as a process of promoting and persuading prospective customers through oral presentation for sale. Personal selling is sometimes referred to as the „last meter” of marketing effort, which is the distance between seller and customer (Clow and Baack, 2008). As Poliačiková (2007) describes personal selling is a face to face deal to present the product, answer questions and get an order with one or more potential customers.

Effective communication with customers works to their satisfaction, which for companies in today's markets is the basis for success and sustainability in the market. To meet these goals, each department of the company is required to meet specific customer desires. As stated by Lucina (2014), each customer has to be taken as a unique personality and to adapt the way of communicating on the basis of his or her family, generation or age. The seller approach should be non-manipulative, responsive and sensitive. According to Colletti and Fiss (2006), the sales environment requires sellers to have individual skills and abilities. The customer and the seller should be equal participants in the communication process. It should be noted that the role of the seller has become less dominant than it was before, so it has moved a lot to the customer side.

At the personal sales level, it is possible to understand the seller from six different positions. The listed characteristics are ranging from the least creative to the most creative sellers (McMurry 1961):

1. Delivery man - delivers the product,

2. Order Receiver - receives orders inside or outside the business,

3. Missionary man - does not accept orders, but he or she creates a reputation of the company and the voice of current and potential customers,

4. Technician - has a high degree of technical knowledge,

5. Creator of demand - relies on creative methods of selling products or services,

6. Solution Provider - meets customer needs.

As Shannahan (2013) states customers can also be actively involved in the communication partnership in sales and product information serve not only for presentation purposes but also for reducing uncertainty. In the context of personal selling, the seller performs the task of collecting and disseminating information in order to establish a friendly relationship.

\section{GENDER DIFFERENCES IN CUSTOMER BUYING BEHAVIOR}

As in every area, the shop is also a place where customer buying behavior was affected by gender differences and different tendencies in their behavior. The explanation of gender can be divided into three levels (Birknerová et al. 2017):

1. Socio-structural level - gender is a classification system that can characterize relationships between women and men in the area from their power status to their social roles.

2. Interpersonal level - defines gender more closely with the ancestral roles that lead to different behaviors that signal and reinforce gender stereotypes in everyday human interactions. 
3. Individual level - the gender is significant at this level in terms of internalizing the gender identity of the individual. Individuals thus become gender-specific, thus gradually attributing characteristics, roles, and behaviors that are desirable for women and men in their own culture.

In a study of gender differences, Benko and Pelster (2013) states that even experienced traders observe the different behavior of women and men. They state what are the most frequent differences and their use in trading, however they suggest only a tendency towards a certain type of behavior, not guaranteed and stereotyped expressions. On the other hand, is the claim that if every individual in a shopping behaves uniquely, then it loses the meaning of these general and generalized claims about a particular group, segment.

There are a number of studies that confirm different purchasing behaviors from a gender perspective. As Benko and Pelster (2013) report, women in buying behavior tend to collect important information during the actual purchasing process. They enter the shop with a certain idea, but they are also open to the other possibilities that occur during the meeting itself. Men focus their attention on a particular role and do not change their plans and activities during the purchasing process. They trust more in their judgment and decide faster than women. Price offers are considered by women to be a source of information and guidance in the issue and often require variants that are not listed and explore options form multiple sellers. Men tend to limit their decision-making based on offers and catalogs and do not like to explore other alternatives. Jones et al. (1998) examined the role of gender in forming a relationship between seller and buyer. They found that the perception of this relationship depended on the seller's and the buyer's gender, the relationship being perceived as stronger when the seller and the buyer are of the same gender. In the study Homburg and Stock (2005) is shown that the relationship between the seller and the buyer is positively moderated by seller's empathy, expertise and reliability. The research by Mitchell and Walsh (2006) shows that women are more perfectionist than men. Men are less sensitive to news and fashion and women are more likely to get confused.

\section{RESEARCH METHODOLOGY}

The aim of the research was to analyze differences in the perception factors influencing personal selling from the point of view of customers in the context of gender differences. Based on the above objective, the hypothesis was established: „We assume that there are statistically significant differences in the perception factors affecting the effectiveness of personal selling by the seller between men and women."

The data obtained were processed and interpreted at the level of descriptive statistics and inductive statistics using the T-test, and the results were processed by the mathematical-statistical methods in SPPS 20. The presented research was carried out by means of a questionnaire, which was divided into four parts: The impact of the seller's image on the customer (items 1-4), The impact of the seller's willingness and empathy on the customer (items 5-10), The impact of the seller's communication skills on the customer (items 11-15) and the impact of the seller's awareness on the customer (items 16-20).

The research sample consisted of 243 respondents, of whom 112 were men and 131 were women aged between 19 and 64 years, with an average age of 39 years. The research participants were to respond on the scale from 1 to 6 to what extent they agree with the given statement $(1=$ definitely no, $2=$ no, $3=$ rather no, $4=$ rather yes, $5=$ yes, and $6=$ definitely yes). 


\section{RESEARCH RESULTS}

In our research, we focused on identifying gender differences in perceived factors (the seller's image, the seller's willingness and empathy, the seller's communication skills, negotiating skills and information) affecting personal selling from the perspective of customers in the context of gender differences. Differences were detected through the Student T-test for two independent selections in the statistical program SPSS 20. The results of the conducted research are presented in Table 1, with statistically significant gender-based differences found in six questionnaire items.

Table 1: Gender differences in the perception factor affecting personal selling from the customers' perspective

\begin{tabular}{|c|c|c|c|c|c|}
\hline Questionnaire Items & Gender & $M$ & $S D$ & $t$ & $\begin{array}{c}p \\
\text { Sig (2-tailed) }\end{array}$ \\
\hline \multicolumn{6}{|c|}{ Image } \\
\hline \multirow{2}{*}{$\begin{array}{l}\text { 1. It is easier to make a purchase when } \\
\text { I have a good impression from the } \\
\text { seller. }\end{array}$} & Male & 4,05 & 1,111 & \multirow[b]{2}{*}{$-2,884$} & \multirow[b]{2}{*}{0,004} \\
\hline & Female & 4,43 & ,903 & & \\
\hline \multirow{2}{*}{$\begin{array}{l}\text { 3. When the seller is dressed untradi- } \\
\text { tionally, I cannot concentrate well. }\end{array}$} & Male & 2,56 & 1,105 & \multirow{2}{*}{$-3,433$} & \multirow[b]{2}{*}{$\mathbf{0 , 0 0 1}$} \\
\hline & Female & 3,05 & 1,118 & & \\
\hline \multirow[t]{2}{*}{ 4. The smiling seller looks fake. } & Male & 3,13 & 1,236 & \multirow{2}{*}{1,903} & \multirow{2}{*}{0,050} \\
\hline & Female & 2,85 & 1,085 & & \\
\hline
\end{tabular}

Willingness and Empathy

\begin{tabular}{|l|c|c|c|c|c|}
\hline $\begin{array}{l}\text { 5. Ifeel more confident when I feel un- } \\
\text { derstanding from the seller. }\end{array}$ & Male & 4,51 & 1,022 & \multirow{2}{*}{$-2,103$} & \multirow{2}{*}{$\mathbf{0 , 0 3 4}$} \\
\cline { 2 - 4 } & Female & $\mathbf{4 , 7 6}$ &, 840 & & \\
\hline $\begin{array}{l}\text { 7. I have a good feeling when the seller } \\
\text { accepts my opinion. }\end{array}$ & Male & 4,58 &, 983 & \multirow{2}{*}{$-2,500$} & $\mathbf{0 , 0 1 3}$ \\
\cline { 2 - 4 } & Female & $\mathbf{4 , 8 5}$ &, 725 & & \\
\hline
\end{tabular}

Communication skills

\begin{tabular}{|r|c|c|c|c|c|}
\hline $\begin{array}{r}\text { 11. When the seller is interested in my } \\
\text { opinion, he or she gets my sympathy. }\end{array}$ & Male & 4,28 & 1,149 & \multirow{2}{*}{$-2,969$} & \multirow{0}{*}{$\mathbf{0 , 0 0 4}$} \\
\cline { 2 - 4 } & Female & $\mathbf{4 , 5 6}$ & 0,882 & & \\
\hline
\end{tabular}

Gender differences between males and females were recorded in items 1, 3, 4 (Factor - Seller's Image, Figure 1) 5 and 7 (Factor - Seller's willingness and empathy, Figure 2) and 11 (Factor Seller's communication skills, Figure 3). In item 1: „It is easier to make a purchase when I have a good impression from the seller." the responses of men and women varied slightly. In the answers above, women (4.43) who tended to respond yes, in contrast to males (4.05), who preferred a less exact response to the scale of ,rather yes than no.” Women need a good impression from the seller. Men perceive this aspect less significantly than women.

Similarly, in item 3: „When the seller is dressed untraditionally, I cannot concentrate well”, we saw differences between men and women, where the women again scored more (3.05) than men. Men (2.56) responded to the ,rather no than yes” and „no” interfaces; for women, the response was ,rather no than yes". In contrast to the previous claim, men and women also have moderate values, and the modus value in females was 3 and in males, 2 . Women were more explicitly inclined to respond ,rather yes than no". We can conclude that there are statistically significant gender differences in the perception of an untraditionally dressed seller and its impact on customer's concentration. Women are more influenced by the outfit of the seller than men. 
In item number 4: „The smiling seller looks fake”, the measured average values for women were 2.85 and for men 3.13, which in both cases represent the ,rather no than yes” response. The men score was higher for the first time. The men's response modus was „no" response, and for women it was „rather no than yes”. We can say that positive attitude and smile at seller are more effective for men than for women.

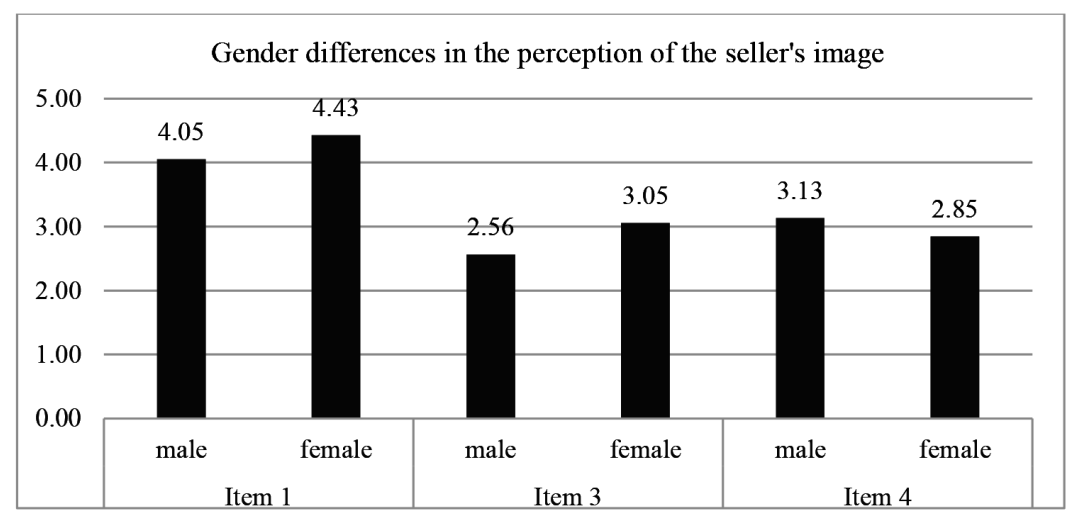

Figure 1: Mean Values of Items focused on the factor: Seller's Image

Item 5: „I feel more confident when I feel understanding from the seller” also confirms the occurrence of statistically significant differences between men and women. The average men response (4.51) moved from „rather yes than no" and ,yes” interfaces, while women (4.76) responded more explicitly and leaned forward to the ,yes” response. We can also say that women require more understanding and certainty when purchasing than men.

In the $7^{\text {th }}$ item of the questionnaire: „I have a good feeling when the seller accepts my opinion.” The responses of men and women were different, while women scored higher (4.85) than men (4.58) again. Women tended to respond more clearly to ,yes," and men responded mainly to the „rather yes than no" and „yes” responses. It can be affirmed that there is a statistically significant difference in the gender perception of the impact on a good customer feeling when the seller accepts his or her opinion.

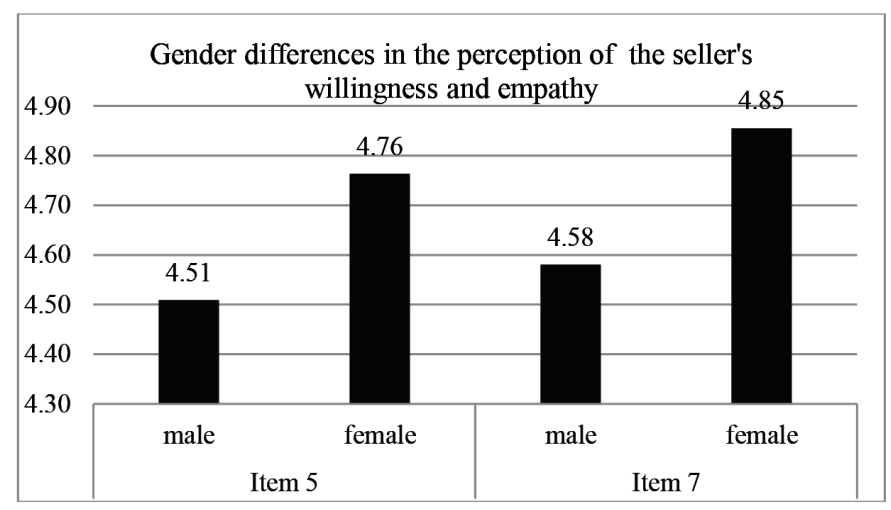

Figure 2: Mean Values of Items focused on the factor: Seller's willingness and empathy 
The last item in which statistically significant gender differences were showed is item no. 11: „When the seller is interested in my opinion, he or she gets my sympathy." In this statement, women scored higher (4.56), answering the „rather yes than no" and ,yes” interfaces. The men (4.28) leaned in response to ,rather yes than no". This argument points to the fact that if sellers are interested in selling and interested in their customers, it is possible that they will get sympathy mostly from women.

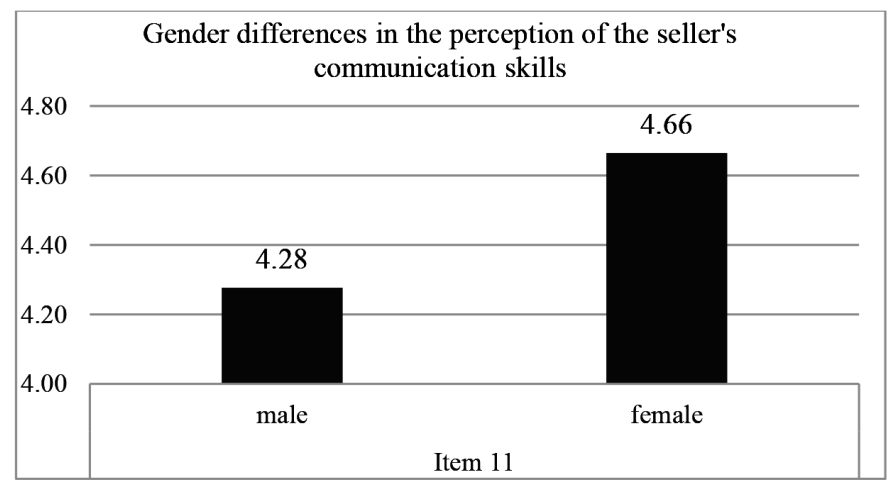

Figure 3: Mean Values of Items focused on the factor: Seller's communication skills

On the basis of the analysis described in Table 2 and Charts 1-3, which compare the perceptions of men and women on the seller to have access to a personal selling, we can say that the hypothesis: „We assume that there are statistically significant differences in the perception factors affecting the effectiveness of personal selling by the seller between men and women," is confirmed.

\section{DISCUSSION AND CONCLUSION}

The presented contribution is aimed at approaching the issue of different perceptions of factors influencing the purchasing behavior of men and women in personal selling. With regard to gender differences, the aim was to analyze gender differences in the perception of factors influencing the effectiveness of personal selling by the seller from a customer perspective. The survey was conducted using the questionnaire method using mathematical-statistical methods and the total number of respondents was 243. Statistically significant differences were showed in the sixth questionnaire items $(1,3,4,5,7,11)$, which are supported by the following factors: Seller's image, Seller's willingness and empathy and the Seller's communication skills. In the last „Seller's awareness” factor, there were no statistically significant differences from the point of view of the customer's gender.

On the basis of the research and its subsequent processing through statistical calculations, we have found that there are areas where the customer's perception of the seller in personal selling between men and women varies.

Both men and women naturally make it easier to make a purchase, if they have a good impression from the seller. However, based on our research, we can assume that there are some differences in gender perception, purchasing decisions, if the customer has a good impression from the seller. Good impression from the seller on women also makes it easier to buy, more than for men. A courteous and friendly seller is valued by both genders. Interestingly, there is a stronger disconciliation among women if the salesperson is dressed untraditionally. Men perceive this aspect less 
sensitively than women. Here we can assume that if men serve a woman, this connection is positively evaluated from the point of view of men. On the other hand, women may be more attracted to men-sellers in their personal selling. Smiling seller is not perceived as fake for men and also for women. However, men in this case with little difference can perceive such access for the sellers artificially and mechanically.

Based on our research, we can conclude that there are gender differences in the perception of factors affecting the purchasing behavior of men and women in personal selling. Sellers can contribute to positive and negative customer feelings. Women admit that they feel confident when the salesperson is receptive to and has understanding for them. Men do not trust the sellers so much. In both cases, without significant difference, interest in the purchase declines if the salesperson does not pay enough attention to them. Since the answer to this claim was „rather yes than no”, we can assume that this fact is also related to the purchase type, and naturally, the strength of this factor may also be different for different purchases. Both men and women have a good feeling if sellers can accept their opinion, which is somewhat appreciated by women. If the seller is able to identify the customer requirements, there is a higher likelihood that customer will buy it repeatedly.

The subject of our research was also the study of gender differences in the perception of the sales skills of the salesperson. Adequate gesture can also influence customer attention and also affect both genders. It affects men and as well as women, if the salesperson knows the right arguments to defend against unauthorized criticism. If the seller is interested in women's opinions, there is a stronger sympathy than in men. It is not entirely clear to men that they are sympathetic if the seller is interested in their opinion. Providing contact with the seller for the case of additional information suits both men and women. Research has confirmed that the perception of men and women is different in the case of the image of the seller, his or her communication skills and his or her awareness.

\section{ACKNOWLEDGMENT}

Scientific paper was elaborated within the framework of the project KEGA 0033PU-4/2017 Implementation of interpersonal skills in the context of the Psychology of business - innovation of contents and teaching.

\section{REFERENCES}

Benko, C. \& Pelster, B. (2013). How Women Decide. Harvard business review. Retrieved from https://hbr.org/2013/09/how-women-decide.

Birknerová, Z., Frankovský, M., Zbihlejová L. and V. Parová. (2017). Gender differences in perception of advertising in the context of expectations of advertising. Journal of applied economic sciences. 12(6), 1751-1758.

Clow, K. E. \& Baack, D. (2008). Reklama, propagace a marketingová komunikace. Brno: Computerpress.

Colletti, J.A. \& Fiss, M.S. (2006). The Ultimately Accountable Job: Leading today's Sales Organization. Retrieved from https://hbr.org/2006/07/the-ultimately-accountable-job-leading-todays-sales-organization.

Homburg, Ch. \& Stock, R.M. (2005). Exploring the conditions under which salesperson work satisfaction can lead to customer satisfaction. Psychology \& Marketing, 22(5), 393-420.

Jones, E., Moore, J.N., Stanaland, A. \& Rosalind, A.J. (1998). Salesperson Race and Gender and the Access and Legitimacy Paradigm: Does Difference Make a Difference? Journal of Personal Selling \& Sales Management, 18(4), 71-88. 
Kita, J. et al. (2005). Marketing. Bratislava: Wolters Kluwer.

Kotler, P. \& Keller, K.L. (2013). Marketing management, Praha: Grada Publishing.

Lucina, R. (2014). Na čo firmy zabúdajú pri svojej orientácii na zákazníka. Zisk manažment, 6(1), 32.

McMurry, R.N. (1961). The Mystique of Super-Salesmanship. Harvard Business Review In Kotler, P. \& Keller, K.L. (2013). Marketing management. Praha: Grada Publishing

Mitchell, V.W. \& Walsh, G. (2006). Gender differences in German consumer decision making styles. Journal of Consumer Behaviour, 3(4), 331-346.

Pelsmacker, P. et al. (2003). Marketingová komunikace. Praha: Grada Publishing.

Poliačiková, E. (2007). Marketing I. Banská Bystrica: Ekonomická fakulta UMB, OZ Ekonómia. Shannahan, J.R. et al. (2013). Making Sense of the Customer's Role in the Personal Selling Process: A Theory of Organizing and Sensemaking Perspective. Retrieved from https://www.tandfonline.com/doi/abs/10.2753/PSS0885-3134330302. 